\title{
9: 34643932-34651884
}

National Cancer Institute

\section{Source}

National Cancer Institute. 9: 34643932-34651884. NCI Thesaurus. Code C42529.

Physical location of IL11RA_Gene 